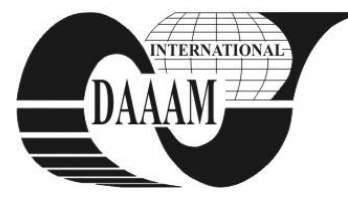

Annals of DAAAM for 2011 \& Proceedings of the 22nd International DAAAM Symposium, Volume 22, No. 1, ISSN 1726-9679 ISBN 978-3-901509-83-4, Editor B. Katalinic, Published by DAAAM International, Vienna, Austria, EU, 2011 Make Harmony between Technology and Nature, and Your Mind will Fly Free as a Bird Annals \& Proceedings of DAAAM International 2011

\title{
USE OF THE HIGH-SPEED CAMERA IN SELF-DEFENCE
}

\author{
LAPKOVA, D[ora]; ADAMEK, M[ilan] \& MALANIK, Z[denek]
}

\begin{abstract}
The article deals with the use of high-speed camera in self-defence. It aims at outlining varieties of applications and describing selected applications. It also brings attention to the fact that the science involved in these issues is missing as well as a complete lack of scientific measurements and experiments in this field. I describe my own research which deals with the speed of the fist movement during a direct punch. A description of the experimental process with its elements and results creates part of this article. Pictures and graphs are included for illustration.
\end{abstract}

Key words: self-defence, high-speed camera, speed, direct punch

\section{INTRODUCTION}

Self-defence represents a field which concerns us in every day life; it is so, even though it may not be visible.

"The primary task of self-defence is to defend (protect) oneself, one's close people, one's interests and merits against an unjust (illegal) attack from another person or people. It is also possible to help against an unjust attack to a stranger within the scope of self-defence. There are five features of selfdefence. Personal interests, mainly life, health, assets, personal liberty, housing liberty and honour, are usually being defended (protected). A person is motivated to self-defence by higher merits which stand outside financial or material profit. These merits are predominantly emotional ties to a close person, to material possession and other merits (for example justice, etc.). Self-defence especially applies to an individual citizen who has standard civil rights." (Lukáš, 2011)

Every day, when we turn on the television and watch the news, or when we read the newspaper, we hear about a number of cases of attacks, robberies, harassment, rape and so on. The media is concerned with the beginning (the assault) and the result; that is - if the victim defended themselves or not. In the end it also deals with if the police were successful in capturing the offender or not and about their possible motive. The process of an assault is not a frequently discussed topic. We all know that we should not walk through dark places and should not get into a car with strangers, but we have not heard much about the fact that the attacking person is usually a person we know and also about the fact that the attack is usually carried out unexpectedly, from a shelter, from the side or from the back. We may only wonder why these facts are not as well known. Why do we not discuss what the assaults look like, what can the victims expect and how can the victims defend themselves? The problem does not lie in the lack of interest as there are many applicants for self-defence courses. I suppose that there would be an incredible demand for the information on, for example, the pickpockets' techniques, what we need to pay attention to, how to enter an apartment or a building without letting any other person in, etc.

From my point of view, the biggest problem is in the lack of scientific experiments and scientific data in this field. It is important to ask, why we should involve science. We must find the answer to the questions if there is a need for scientific experiments and if they are capable of helping us or if they are just a waste of time and money.

The evidence for this necessity is the everyday presence of violent crimes. We see on the news that people's aggressiveness is increasing and various kinds of violence are increasing, but we are not that aware of the actions that have been taken to stop it. Apparently, the crime rate in on the increase as well, but the measures to fight it remain the same.

On one hand, the public sees all the evil that is present in the world, they know that the police cannot be at every place at one time, they know how the offenders are punished and that in a couple of years (sometimes it is true literally) the offenders are free again. On the other hand, the public still relies on somebody else who would defend them or some act of god which will ensure that nothing evil will happen to them.

\section{THE SPEED OF DIRECT PUNCH}

Punches are one of the basic techniques taught in selfdefence courses and that is the reason why I focus particularly on this technique and particularly on the direct punch of the stronger arm. In my opinion, it is the most natural type of punch and thus I decided to begin my research with it. We are concerned with the questions of how strong the punch is, if it was a punch by a professional or a layman, what kind of injury it could have caused etc. Some of these questions may be answered by detecting the speed of the punch and by examining individual elements of this movement.

The high-speed camera system Olympus i-SPEED 2 was used for filming the process of the arm movement, and the fist in particular, during the direct punch. This type of punch was chosen for the above stated reason and also because it is the easiest punch to film and subsequently evaluate its speed.

The measuring site consisted of a construction for hanging the square punching bag. The punching bag itself was the target for striking and the above mentioned high-speed camera system. The measuring started at a certain distance from the surface which was to be struck and the end was at the termination of the fist movement in the forward direction - that means at the point where the deformation of the material reached its maximum.

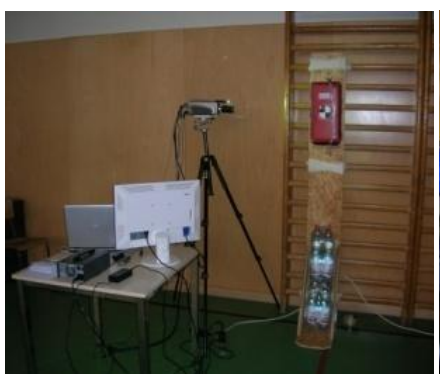

Fig.1. Measuring Site

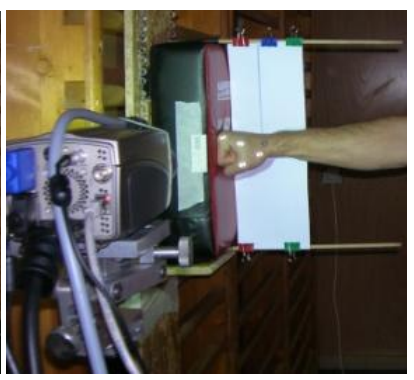

Fig.2. Detail of Filming the Direct Punch 
The activity has resulted in a record of the whole process of the fist movement during the punch as well as calculating the speed of the fist movement. This speed is presented in following graphs which are separate for men and for women. One may discover in these graphs that the speed of the fist movement is lower in the case of women than in men and that the duration of the punch is shorter in the case of women.

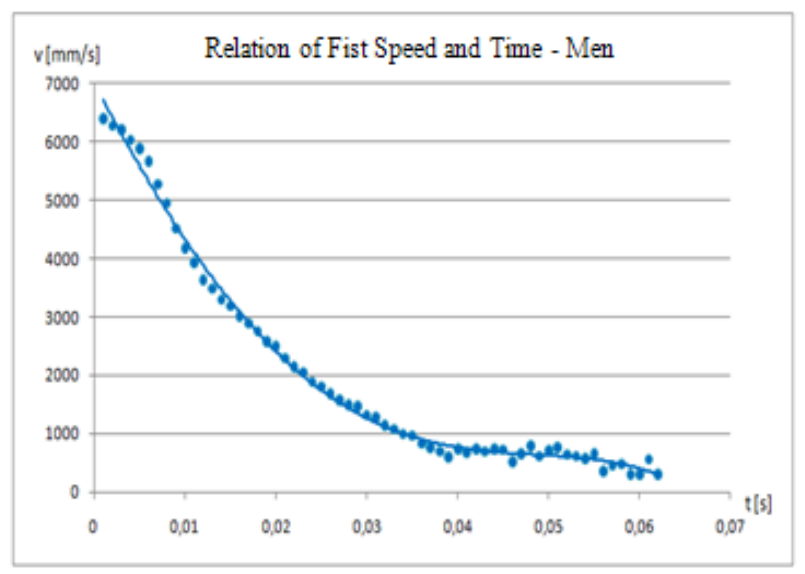

Fig. 3. Relation of Fist Speed and Time - Men

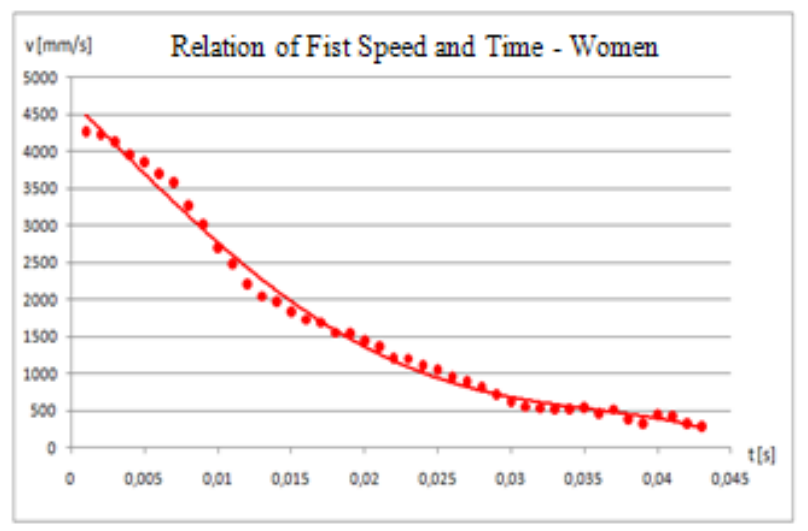

Fig. 4. Relation of Fist Speed and Time - Women

\section{RECORD OF DEFECTIVE PUNCHES}

A record of the fist movement itself is the additional thing that may be used; and the contact of the fist with the striking target in particular. This may be used mainly during the learning process and while explaining the most frequent mistakes people make when they carry out the direct punch. These are: loose wrist which bends back as a consequence or not punching with the correct part of the fist (when the punching is not carried out with the first two knuckles but with the whole fist).

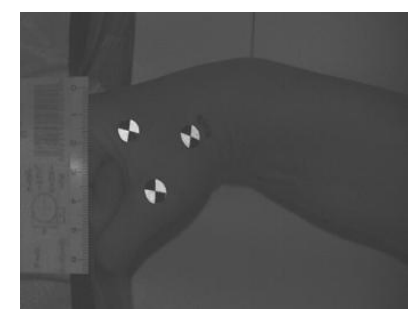

Fig. 5. Defective Punch 1

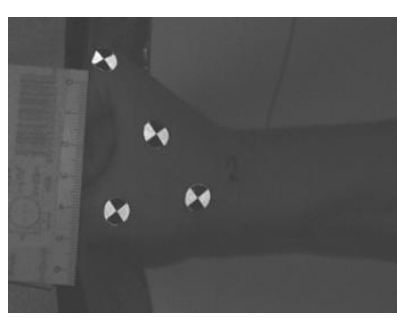

Fig. 6. Defective Punch 2
The pictures above depict the most frequent mistakes which may disclose that these punches were not performed by trained people, but rather laymen. In fact, the people participating in the experiment were students who have taken at least one year of Special Physical Training at the Tomas Bata University in Zlín. Self-defence is taught in this course, so the students should be familiar with the technique of punching. They are not trained professionals, but they are not complete laymen either. 13 men and 6 women took part in this research.

\section{CONCLUSION}

The possibilities of scientific research in this field are immense and the field has not been examined much. The speed of the direct punch is only the beginning; however, it may help us with answering a couple of questions, but definitely not all the questions. The next information we may obtain, is the relationship of the speed of the fist movement during the direct punch to the gender. We can also discover if there is any relationship to height, weight, training etc.

This paper introduces the utilization of high-speed camera in self-defence. The research so far focuses on untrained people whose speed of direct puch was tested. The furter research will be focused on trained people and a wider range of techniques (various punches and kicks) will be examined.

Self-defence is a field which is entered by many laymen. They talk about something they do not understand and the worst thing is that they keep teaching the techniques that do not work at all but look nice. In such cases the person pays for a course, where they learn several techniques which look nice and work in the gym, when they are in sweatshirts and with a sparring partner who is willing to fall down after they have used the technique. Then, this person comes home and wants to show their friends what they have learnt and suddenly, the technique does not work. It is inevitable that the person does not trust it any more and is disillusioned. Unfortunately, at present anybody can start their own school or club and "teach". This fact only causes the mistrust in these courses and reluctance to attend these courses.

That is the reason why science must be included in selfdefence as much as possible. This science may help to avoid teaching techniques which do not work and also help people feel safer. They do not have to rely on somebody else for their defence any more and they do not have to spend a lot of money on useless courses.

\section{ACKNOWLEDGEMENTS}

This paper is supported by the Internal Grant Agency at TBU in Zlin, project No. IGA/26/FAI/11/D and by the European Regional Development Fund under the project CEBIA-Tech No. CZ.1.05/2.1.00/03.0089.

\section{REFERENCES}

Konečný, A. (1997). Sebeobrana a úpolová cvičení pro pokročilé (Self-defence and Resistance Exercise for Advanced), Univerzita Palackého, ISBN 80-7067-766-x, Olomouc

Lapková, Dora. (2007). Sebeobrana ženy (Self-defense of a Woman), Univerzita Tomáše Bati ve Zlíně, Zlín

Lapková, Dora. (2009). Specifikace napadení ženy a zpưsoby jeho řěsení (Specifics of Attacking a Woman and Means of its Solution), Univerzita Tomáše Bati ve Zlíně, Zlín

Lukáš, Luděk, et al. (2011). Bezpečnostní technologie, systémy a management I. (Security Technologies, Systems and Management 1.), VeRBuM, ISBN 978-80-87500-05-7, Zlin

Náchodský, Z. (2006). Nebojte se bránit bránit (Do not be Afraid to Defend Yourselves), Armex Publishing. ISBN 8086795-43-8, Praha 